\title{
Changes in yield and seed quality traits in rapeseed genotypes by sulphur fertilization
}

\author{
Cem Ömer Egesel · M. Kemal Gül · Fatih Kahrıman
}

Published online: 5 July 2009

(C) Springer-Verlag 2009

Erratum to: Eur Food Res Technol (2009) 229:505-513

\section{DOI 10.1007/s00217-009-1067-3}

Unfortunately, the printed version of article contains Turkish words in the column 1 of Table 1 . Corrected version of Table 1 is given below with English words.

Table 1 Soil characteristics for the experimental area

\begin{tabular}{lll}
\hline Parameter & 2006 & 2007 \\
\hline $\mathrm{pH}$ & 6.4 & 7.8 \\
Lime (\%) & 2.6 & 18.6 \\
Salt (\%) & 0.025 & 0.020 \\
Sand (\%) & 44 & 54.1 \\
Org matter (\%) & 2.1 & 1.4 \\
Total N (\%) & 0.106 & 0.090 \\
S (ppm) & 55.6 & 12.74 \\
\hline
\end{tabular}

The online version of the original article can be found under doi:10.1007/s00217-009-1067-3.

C. Ö. Egesel $(\varangle) \cdot$ F. Kahrıman Department of Field Crops,

Çanakkale Onsekiz Mart University,

17020 Çanakkale, Turkey

e-mail: cegesel@comu.edu.tr

M. K. Gül

COMPO GmbH Co. KG Turkey Liasion Office,

Büyükdere Street, No: 7 GIZ 2000 Plaza,

7th Floor, 34398 Maslak, Istanbul, Turkey 